\title{
Possible Applications of Creative Thinking within a Simplex Didactics Perspective
}

\author{
By Iolanda Zollo* \\ Maurizio Sibilio
}

The contemporary proteiform education system characterised by complexity and dynamism and brought about by the acknowledgement of the diversity in students' needs, requires teachers to constantly put into practice numerous problem-solving and decision-making strategies. The underpinning capability required to face challenging situations is a form of cognitive flexibility; i.e. the ability to find alternative solutions and strategies. This approach has been a subject to numerous studies and research, which provide worthy evidence on the role of creative thinking to apply detour strategies during the teachinglearning processes so as to respond to the inherent need to have a plurality of solutions to ensure a better control of the system at one's fingertips. The article presents the underpinning theory and the activities suggested for the organisation and delivery of the workshops sessions on simplex didactics aimed at in-service teachers and primary school pupils as part of a teachereducation course.

Keywords: creative thinking, inclusive education, simplexity, simplex workshops, teacher education

\section{An Introduction to the Italian Educational Contexts}

The social and cultural mutations, the development of technology, the new learning styles and the emerging learning differences of students as a result of physical or cognitive disability, Specific Learning Disorders such as dyslexia, or disadvantages due to socio-economic, linguistic and cultural backgrounds, are some of the aspects which have determined the complex situation, characterising the Italian educational contexts (Rivoltella \& Rossi, 2012; Chiappetta Cajola \& Ciraci, 2013; Sibilio 2014).

In addition, in line with the international developments of the time (Green, Wolf \& Leney, 1999), the process of decentralisation and autonomy of the educational institutions that was initiated in the late 90s has delineated the shift from a monocentric to a polycentric system. This has favoured the development of a scientific identity of didactics, defined as the science of

\footnotetext{
* PhD Student in Didactics, Inclusive Education and Technology, Department of Humanities, Philosophy and Education, University of Salerno, Italy.

${ }^{\dagger}$ Full Professor in Special Pedagogy and Didactics, Department of Humanities, Philosophy and Education, University of Salerno, Italy. Professor Sibilio is the co-author and the scientific coordinator of the paper.
} 
teaching, which in turn brought about a greater focus on the centrality of the role of the teacher in the teaching-learning process.

This centrality finds its basis on two levels. Firstly, the ongoing research on enactive didactics (Rossi, 2011), neurodidactics (Rivoltella, 2012) and simplex didactics (Sibilio, 2014); all sharing a common view that the learning experience, is complex, systemic, adaptive and transdiciplinary. Secondly, in the most recent regulatory actions ${ }^{1}$ that to promote the processes of inclusion of students with special educational needs, priority has been placed on the preparation of teachers able to promote inclusion through their choices of instruction.

As a result of this scenario, what gains relevance is a complexa quaestio, which oscillates a between tradition, innovation and the capability to bring about change. Within a systemic perspective, the professional quality of teachers has been found to be highly correlated to school performance and students' with educational and social success (Darling-Hammond, Bransford, LePage, Hammerness \& Duffy, 2005; Organisation for Economic Co-operation and Development, 2005; Rivkin, Hanushek \& Kain, 2005; Schwerdt \& Wuppermann, 2011). In fact, unless teachers possess the essential tools to interpret the didactic processes, they are not able to reflect on their work, on their teaching and on the ways with which the latter can improve the teachinglearning processes in order to become aware of the quality of their own competencies.

In the proteiform reality of Italian educational contexts, an educational investment is requested from teachers through the development of different and efficacious strategies of problem solving and through a flexible and creative organisation of their didactic itineraries. The ultimate aim is that of responding to one's own professional needs, meet the requirements of each and every student, and bring to light their potential, removing any obstacle and learning barrier and favouring full participation in school (World Health Organization, 2001, 2007; European Agency for Development in Special Needs Education, 2012). Hence, creative thinking, intended as an instrument to create deviations from stereotyped actions, may offer a new perspective if applied in educational experiences embedded in the construction of teacher competencies. As a result, this could reveal itself as an interesting strategy to decipher and face the complexity and the plurality of challenging situations (Canevaro, 2013; Sibilio,

\footnotetext{
1 Since 2009, following the approval of the Convention on the Rights of Persons with Disabilities (2006), in Italy the prospect of full inclusion was endorsed and, as a result, a series of regulatory actions have been issued. The Law of 8/10/2010, n. 170 and the Guidelines of 12 July 2011, in addition to defining the Specific Learning Disorders (SLD), provide evidence of the importance of the shared responsibility of all teachers in the preparation and implementation of the educational plan envisaged for children with learning disorders, thus restoring to teacher training a prominent role. The inclusive strategy of the Italian school is outlined in the Ministerial Directive of 27 December 2012 and in its Ministerial Circular March 6, 2013, n. 8: This document, based on a global view of the person with reference to the biopsycho-social model proposed by ICF (World Health Organization, 2001), provides a precise definition of the concept of "Special Educational Needs" (SEN) and places special attention to increasing the skills of teachers through the activation of specific Masters courses and professional development courses.
} 
2014).

Such cognitive flexibility has constituted the leitmotif of a plethora of research on the theme of creativity (Guilford, 1950; Mednick, 1962; Torrance, 1966; Beaudot, 1977; Boden, 1990; Gardner, 1983; Runco \& Richards, 1997; de Bono, 1998; Goleman, Ray \& Kaufman, 1999; Runco, 1999; Sternberg, 1999), from which a number of interesting reflection emerge regarding the possible didactic application and educational implications of such theories. This has also been supported by international scientific literature aimed at exploring the creative aspects among the identification of teachers' core competencies (Argyris \& Schön, 1978; Schön, 1983; Van Manen, 1993; Ghaye \& Ghaye, 1998).

\section{Creativity, Simplexity and Vicariance: a Brief Literature Review}

In the last decades, the recognition of the potential of creativity has been gaining momentum. Creativity, is intended as "a typical process of the human brain naturally structured to think creatively"(my translation) (Cesa-Bianchi, Critini \& Giusti, 2009, p. 14), and not merely as an innate talent, it is an adaptive procedure determined by the necessity and characterised by the elaboration of multiple solutions, which are new, original and not predetermined (Guilford, 1967; Goleman, Ray \& Kaufman, 1999). The peculiar element of creativity is flexibility, which allows the individual to see the same thing from different points of view, to respond with ideas from multiple categories and to confront oneself with changes, thus allowing to put in action a "contaminated" thought rather than an autarkic one (Runco, 1999).

As a result, what emerges from this reflection is the possible didactic application of the theories on creative thinking within the perspective of simplex didactics. Alain Berthoz, physiologist of perception and action at the Collège de France, proposed the theory of simplexity, which is based on the assumption that the solutions elaborated by living organisms to decipher and face complexity can be considered applicable to the entire class of complex adaptive systems (Berthoz, 2012). This, in turn, provides new keys to interpret the didactic phenomenon and enriches reflections in pedagogy through a variety of inputs. Indeed, in Italy, the concept of simplexity led to the proposal of an analogy between didactics (intended as a complex adaptive system) and living organisms. Through the didactic application of its properties, which can be considered as simplex tools, and the principles, defined as simple rules, this concept emerged as a significant opportunity to face the dynamism in the educational contexts (Sibilio, 2014).

Taking into account the theoretical reflections on creative thinking and analysing the concept of simplexity coined by Berthoz (2012), it is possible to identify significant analogies between the two fields. In fact, among the principal characteristics of creative thinking are flexibility, adaptation and detour (Guilford, 1967; Goleman, Ray, \& Kaufman, 1999; Cesa-Bianchi et al., 
2009; Runco, 1999), identified by Berthoz (2012) as simplex properties and principles.

According to Berthoz (2012), the adaptation of living systems requires flexibility and the disposition towards change: "an organism must be able to resolve a problem, perceive, capture, decide, or act in several different ways (vicariance) to adapt to the context, compensate for deficits, and face new situations" (Berthoz, 2012, pp. 9-10). Within the didactic field, flexibility and the adaptation to change are simplex tools which allow teachers to disentangle themselves from the multiple challenges experienced, finding within the challenging situation the opportunity to widen their knowledge through action and to be more open towards different adaptive solutions to avoid getting lost in complexity (Sibilio, 2014).

Alain Berthoz, among the simplex principles, identifies the detour principle as the ability to replace a simple variable one wishes to control with a more complex mix of variables, called composite variables. Taking detours may seem more complex but it actually results in a more simple and efficient control of the system (Berthoz, 2012, pp. 18-19). This principle in didactics responds to the need, embedded in teaching, to search for diverse approaches in teaching, which offer teachers a multitude of solutions that aim at offering more control on the system. These solutions allow the application of the didactic objectives through routes that are not linear and open to change (Sibilio, 2014). In didactics, the detour principle, which can be considered as the manifestation of creative thinking, is aimed at identifying operational strategies that, inhibiting and refusing immediate solutions or those which come as a second nature, to give the teacher the opportunity to identify courses of action able to favor the learning process, even if this may seem more complex.

Inextricably linked to the detour principle is the simplex principle of vicariance: a detour intended as a form of creativity that renders possible thanks to diversity (Berthoz, 2015, p. XIV). This precious tool of living organisms is characterized by an abundance of meanings: its roots stem from the occasional substitution of the curator and the bishop, its semantic field has been widened to embrace the concept of the greek word mètis and further on its meaning developed into the capacity to create, to innovate and to interact with others in a flexible and tolerant manner, substituting a solution with another to solve a certain problem or to use the said solution to solve another one of a different kind (Berthoz, 2015).

In every individual's experience, vicariance represents a powerful adaptive and learning tool. In this respect, Berthoz postulated that "leaving the subject the freedom to find his or her own path [...] means recognizing the diversity of each and every one" (author's translation) (Berthoz, 2015, p. 129). Within the didactic field, the recognition and capitalization of differences, was understood as resources and as elements of positive uniqueness and originality, constitute one of the fundamental values of the inclusive teacher (European Agency for Development in Special Needs Education, 2012). Everyone has his or her own way to learn and as Berthoz affirms "the challenge for learning and 
teaching is not to find a good method, but to discover the more suitable method for each brain" (author's translation) (Berthoz, 2015, p. 132).

In order to find vicarious solutions, the link between memory of past experiences and future scenarios, is fundamental. In fact, vicariance is driven by the projection towards the future (Berthoz, 2015). Therefore, teachers may well anticipate the outcomes of their actions through the capitalization of their own previous experiences and through the identification of their students' needs with the aim of anticipating and resolving a series of complex problems. Vicariant creativity does not limit itself to a mere delegation or substitution. To discover new ways to solve a task, the capability of looking at things from a different perspective by decentralizing oneself is necessary (Berthoz, 2015). Hence, teachers need to be able to change their point of view in order to face complexity within educational contexts and to guarantee the students' educational success.

\section{Simplex Workshops: An Action-Research Proposal}

In line with the theoretical reflections on the possible applications of creative thinking within a simplex didactics perspective, the Department of Human Sciences, Philosophy and Education at the University of Salerno has initiated a project with the Regional Office for Schools for the Ministry of Education in Campania with the aim of planning and delivering a series of simplex workshops. These workshops are aimed at promoting and developing problem solving strategies, first of all among teachers, and successively among students, to face the complexity of the teaching-learning processes.

\section{Objectives}

The project "Simplex Workshops: methodological and didactic approaches to develop metacognitive strategies to face the complexities in educational experiences" aims at delineating innovative, flexible and differentiated didactic interventions utilizing simplex didactics as guidelines and putting in practice a form of vicariant creativity. The activities to be presented are inspired and designed on the basis of recent literature which supports and advocates the importance of developing creative thinking skills for effective problem solving, as outlined earlier.

\section{Methodology}

The activity proposed is a series of workshops on simplex didactics aimed at teachers and students in their third year of primary school (8-year-olds) ${ }^{1}$ in

\footnotetext{
${ }^{1}$ The choice to work with third year primary school children stemmed from the National Curriculum Guidelines (MIUR, 2012) which delegate to primary schools the responsibility to create educational opportunities able to give value to metacognitive competencies in teaching-
} 
20 schools in the region of Campania identified by the Regional Office for Schools for the Ministry of Education in Campania. This project will be based on action research aimed at investigating some forms of didactic applications of simplexity. Through the activities on the properties and the principles proposed, besides constituting an original opportunity to reconsider one's own teaching methods, teachers will be enticed to control and monitor their own teaching to orient it towards the students' success. Meanwhile, thanks to these new teaching strategies, the students will be able to develop effective and flexible metacognitive strategies.

The research project is a descriptive study stemming from a scientific collaboration with Alain Berthoz, and is articulated in the following phases:

- A literature review on the current need of innovative, flexible and creative teaching strategies; on the possible teaching applications of simplexity; and on the importance of development of metacognitive skills;

- Initial collaboration with the schools and teachers. This includes:

$\circ$ a meeting with the school directors and the teachers involved to identify the students' educational needs;

o structured interviews aimed at identifying the teachers' knowledge on the themes of flexible teaching strategies for the development of the students' metacognitive skills;

- a short teacher education course consisting of three meetings to introduce the paradigm of simplexity and its possible applications in teaching;

$\circ$ a meeting with the teachers to discuss the contents and the structuring of the activities to be held with the students;

- Preparation of the teaching resources to be used during the workshops, focusing the attention on the specific themes agreed upon with the teachers and aimed at meeting the students' learning needs;

- Implementation of the workshops;

- Recording, analysis of data and evaluation of process and outcome;

- Outcome evaluation.

\section{Expected Results}

- Development of metacognitive strategies which favor di teaching-learning process through the application of simplex properties and principles;

- The creation and planning of creative, innovative and flexible teaching approaches through simplex workshops.

learning processes in order to promote learning to learn; one of the 8 key competences identified in the Recommendation of the European Parliament and of the Council of 18 December 2006. 


\section{Teaching the Native Language through Simplex Workshops}

Communication in the mother tongue and communication in foreign languages has been identified as the first key competence for lifelong learning in the Recommendation of the European Parliament and of the Council dated 18 December 2006. This entails the capability to express oneself and to interpret concepts, thoughts, feelings, facts and opinions in an oral and written form and to adequately interact in creative ways on a linguistic level within an array of social and cultural contexts, to include education and training, work, everyday life and free time.

The native language is the first tool for communication and access to knowledge. In fact, the development of language competencies can be considered as the condicio sine qua non for personal growth and active citizenship, for critical access to all cultural aspects and to succeed in school life (MIUR, 2012). Reaching these transversal objectives, inevitably establishes that for pupils to learn their native language, be it Italian, Greek, French or English, all teachers, independent of the subject taught, are requested to take on this responsibility.

In Italy, language learning occurs within an anthropological scenario characterized by a variety of elements:

- persistence of dialect, although unequal and diverse among regions;

- the richness and variety of minority languages, for example German in Northern Italy;

- the coexistence of multiple languages from all over the world due to the high incidence of immigration;

- the presence of spoken and written Italian with very different levels of mastery and with marked regional variations.

All this means that in the experience of many children and youths, the Italian language is considered to be a second language. The constant attention paid to the progressive mastery of Italian therefore implies that language learning must start from the language and the communication skills that students have already gained and takes into account their development not only in terms of the betterment of academic performance, but also as an essential skill for life.

On the basis of such reflections, the simplex workshops may provide a methodology through which teachers can promote the development of metacognitive strategies for the acquisition of language competencies among third year primary school pupils, by exploring flexible, creative and non-linear teaching itineraries. The following are some examples related to the teaching of polysemic words. The objectives, in line with the 2012 National Curriculum Indications, are the acquisition of lexis and reflection on the use of language. 
Two phases were identified:

- a detailed analysis of the activities and exercises proposed in text books adopted in schools was conducted (phase 1).

- on the basis of the ideas identified, the activities were reformulated diversifying the language and adopting them as a possible application starting from the application of simplex didactics (phase 2).

\section{Phase 1}

Taking into consideration the activities and exercises available in the textbooks used in schools and with the aim of familiarising students with polysemic words, the following exercises, structured on a gradual increase in the level of difficulty, can be proposed:

Exercise 1. With the help of their teacher the children can observe some images in which the polysemic words are presented. Comparing the drawing and the written text, would not only facilitate learning but promote linguistic reflection.

The first example could be on the polysemic word "albero":

- pianta dotata di un tronco verticale in legno, di ramificazioni e di foglie [A plant with a vertical trunk, branches and leaves] (Treccani, 2015);

- asta verticale che regge le vele delle navi [vertical axis that holds the sails on ships] (Treccani, 2015);

- schema grafico che, con le sue ramificazioni, indica rapporti di derivazione (ad esempio, l'albero genealogico) [graphic scheme with branche sto indicate the relationships among the variables e.g. family tree] (Treccani, 2015).

Figure 1. The Polysemic Word "Albero"

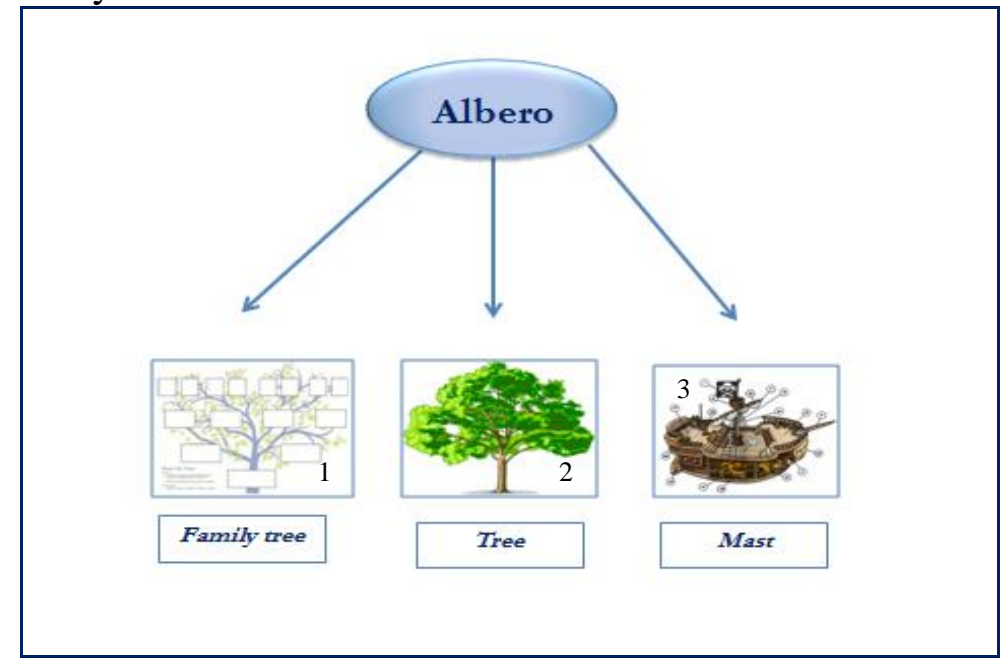


Starting from these definitions the children observe the different images: Contents of the images:

- Da bambino ho sempre desiderato costruire una casa sull'albero [When I was a child I always wanted to build a tree house].

- L'Amerigo Vespucci ha le vele e gli alberi più belli in assoluto [The Amerigo Vespucci has the most beautiful sails and masts].

- Ho ricostruito, assieme a mio nonno, l'albero genealogico della mia famiglia [With the help of my grandfather, I have reconstructed my family tree].

Exercise 2. After the first activity, which is mainly explanatory and observational, a more operational activity follows. The teacher presents two sentences with images and word balloons containing polysemic words asking the children to identify the polysemic words and to explain the meaning depending on the context.

The polysemic words could be:

- "Banco" (1. banca, istituto bancario[bank]; 2. mobile composto da un sedile e un tavolo anteriore d'appoggio [bench]) (Treccani, 2015).

Figure 2. The Polysemic Word "Banco"

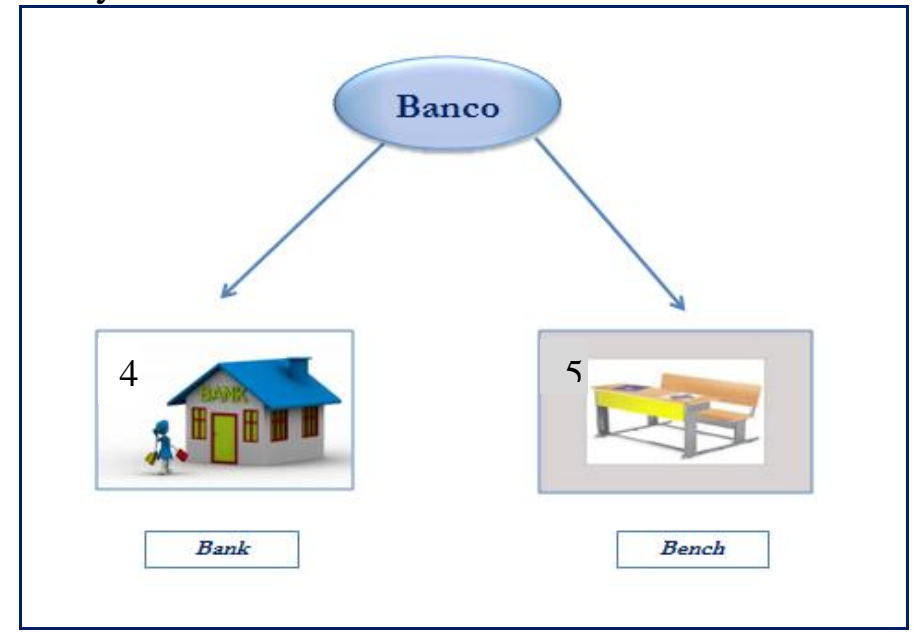

Sentences: 1. Il sabato il banco di Napoli è aperto [On Saturday the bank of Naples is open.]; 2. Marco sarà il mio nuovo compagno di banco [Marco will be my new classmate sitting onthe same bench].

- "Guida" (1. l'azione di guidare [to drive]; 2. chi, per professione, accompagna i turisti nelle visite ai monumenti, ai musei, agli scavi archeologici, etc. [tourist guide]) (Treccani, 2015). 
Figure 3. The Polysemic Word "Guida"

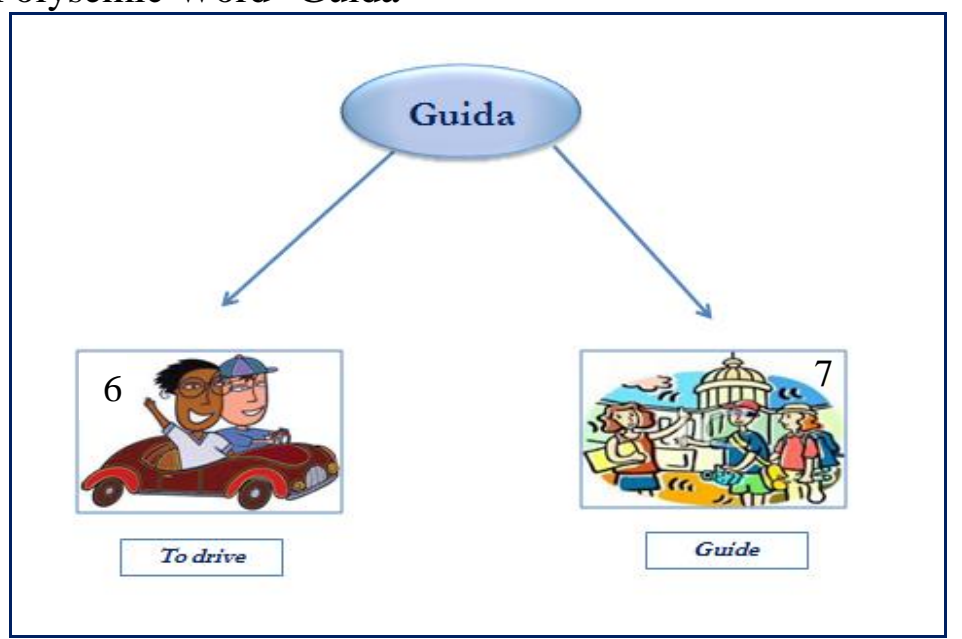

Sentences: 1. Ammiro la guida sportiva di mio padre [I admire the way my father drives]; 2. La guida turistica del museo di Capodimonte è veramente in gamba [The tour guide at the museum is very good].

- "Passato" (1. il tempo ormai trascorso e gli avvenimenti che in esso si sono verificati [the past]; 2. preparazione a base di verdure, patate $o$ legumi [puree]) (Treccani, 2015).

Figure 4. The Polysemic Word "Passato"

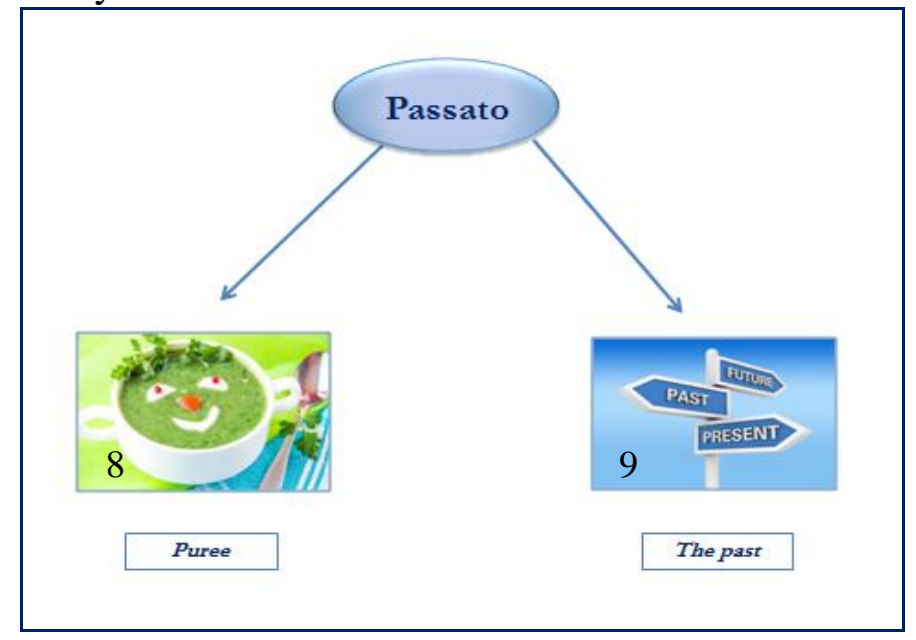

Sentences: 1. Maria adora i libri del passato [Maria adores books about the past]; 2. Alberto detesta il passato di verdure [Alberto hates vegetable puree].

Exercise 3. The last activity could be the following: ask the students to observe two images representing a polysemic word and elaborate one or more sentences with both meanings.

For example the image of the words "saggio" and "divisione" may be introduced: 
- $\quad$ "Saggio" meaning "persona dotata di saggezza" [wise man] and "prova che si affronta per dimostrare le proprie attitudini, la propria preparazione e competenza in un determinato campo o settore [show/soiree organised at the end of the school year" (Treccani, 2015).

Figure 5. The Polysemic Word "Saggio"

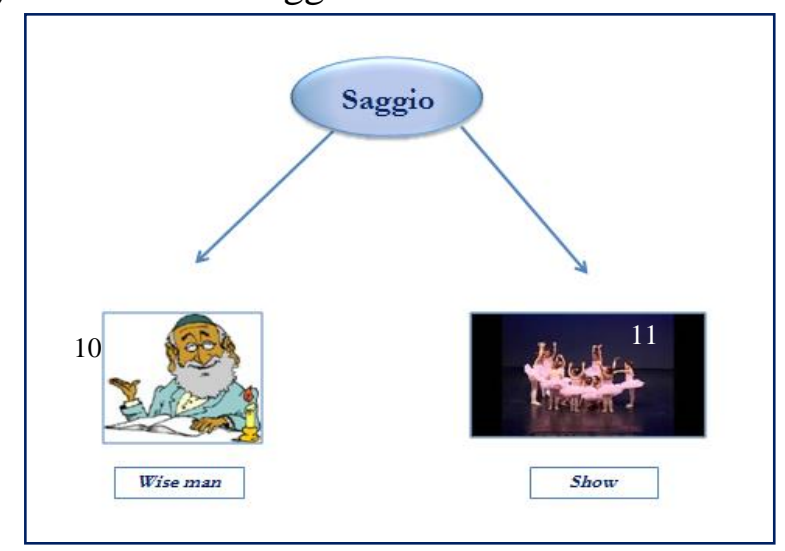

- "Divisione" meaning "l'atto di dividere, sia facendo due o più parti di un tutto, sia disgiungendo o separando cose o persone che erano unite o costituivano un insieme unico [divide meaning separating two or more things that were a whole]" e come "una delle quattro operazioni aritmetiche elementari [to divide in an arithmetic operation]" (Treccani, 2015).

Figure 6. The Polysemic Word "Divisione"

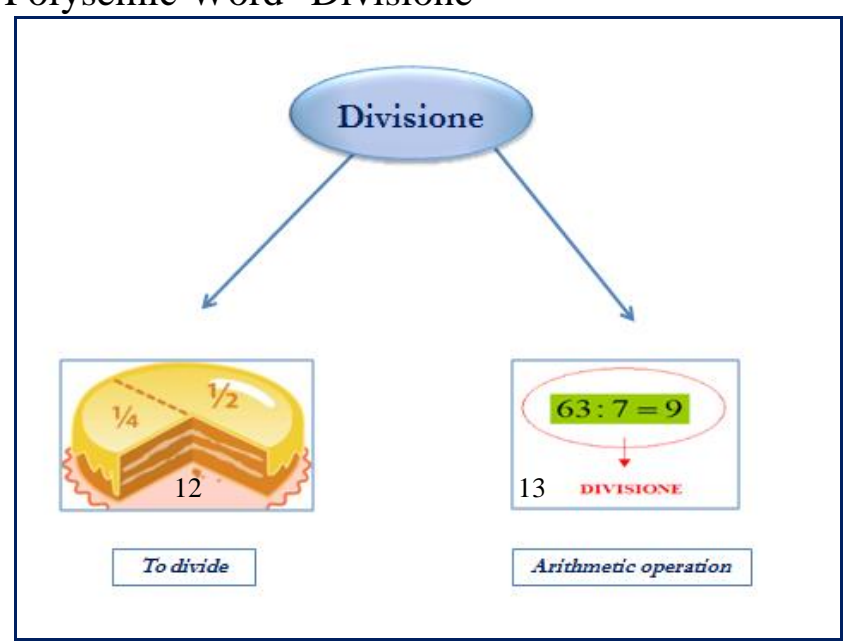

\section{Phase 2: Applying the principles of Simplexity in Didactics}

In the successive phase, in the light of the activities proposed, the simplex principles were applied. In this article, two principles are presented. These are inhibition and the principle of refusal and of the detour, two principles which 
are closely linked with each other.

Inhibition and the Principle of Refusal. In the case of polysemic words, this principle may be used when the student, having acquired the concept, is asked to reflect on the possible meanings in terms of the possibility to confirm the knowledge of the different possible meanings, also through the conscious exercise of refusal and inhibition.

Exercise 1. To verify the acquisition of the concept of polysemic words and to exercise the principle of inhibition and refusal in a conscious manner, children may be asked to reflect on different stimuli presented on a series of flashcards.

Table 1. Principle of Inhibition and Refusal: Content of the Flashcards

\begin{tabular}{|c|c|c|c|}
\hline Questions & Yes & No & Why \\
\hline $\begin{array}{c}\text { L'albero appartiene solo al mondo vegetale? } \\
\text { [Is the tree only part of the plant world?] }\end{array}$ & & & \\
\hline $\begin{array}{c}\text { Gli alberi sono solo presenti nelle barche a } \\
\text { vela? [Are trees (masts) only present on a } \\
\text { sailing boat?] }\end{array}$ & & & \\
\hline L'unico albero è quello genealogico? & & & \\
[Is the tree only the one in the family tree] & & & \\
\hline
\end{tabular}

Exercise 2. Flashcards with word bubbles containing polysemic words can be presented to the children, asking them to identify the polysemic words in the drawings and then give an intentionally wrong meaning in the context so as to use the principle of refusal and inhibition consciously.

The words could be the same used in the previous exercise:

Table 2. The Polysemic Word "Banco": Sentences in Flashcards

\begin{tabular}{|c|c|c|c|}
\hline Sentences & Yes & No & Why \\
\hline $\begin{array}{l}\text { Se l'istituto bancario è un banco e un mobile } \\
\text { composto da un sedile e un tavolo anteriore } \\
\text { d'appoggio, allora possiamo dire che } \\
\text { l'istituto bancario è un mobile composto da } \\
\text { un sedile e un tavolo anteriore d'appoggio? } \\
\text { [If the bank (bench) is a piece of furniture } \\
\text { made up of a seat and a desk, can we say that } \\
\text { the bank (bank) is a piece of furniture?] }\end{array}$ & & & \\
\hline
\end{tabular}


Table 3. The Polysemic Word "Guida": Sentence in Flashcards

\begin{tabular}{|c|c|c|c|}
\hline Sentence & Yes & No & Why \\
\hline $\begin{array}{c}\text { Se l'autista guida e la guida per professione } \\
\text { accompagna i turisti nelle visite ai } \\
\text { monumenti, ai musei, agli scavi archeologici, } \\
\text { allora ogni autista accompagna i turisti nelle } \\
\text { visite? }\end{array}$ & & & \\
$\begin{array}{c}\text { [If the driver drives and the torsi guide takes } \\
\text { tourists around a city to visit museums, can } \\
\text { we say that a driver takes tourists } \\
\text { sightseeing?] }\end{array}$ & & & \\
\hline
\end{tabular}

Table 4. The Polysemic Word "Passato": Sentence in Flashcards

\begin{tabular}{|c|c|c|c|}
\hline Sentence & Yes & No & Why \\
\hline $\begin{array}{l}\text { Se la preparazione a base di verdure, patate o } \\
\text { legumi è chiamata passato di verdure e quello } \\
\text { che è già successo si definisce passato, allora } \\
\text { un preparato a base di verdure, patate e } \\
\text { legumi corrisponde a tutto ciò che è già }\end{array}$ & & & \\
\hline $\begin{array}{l}\text { [If the preparation of vegetables, potaotoes } \\
\text { and legumes is called "passato"(puree) and } \\
\text { that which has already happened is defined as } \\
\text { "passato" (past), then a vegetable puree } \\
\text { corresponds to what happened in the past] }\end{array}$ & & & \\
\hline
\end{tabular}

Exercise 3. The last activity could be that of identifying, through the conscious use of the principle of inhibition and refusal, the errors presented in some of these sentences explain the reasons behind their answers.

- Il "saggio" è una "persona dotata di saggezza" che si affronta per dimostrare le proprie attitudini, la propria preparazione e competenza in un determinato campo o settore [correct definition of wise man] (Treccani, 2015);

- La "divisione" è "l'atto di dividere, facendo due o più parti di cose o persone che erano unite o costituivano un insieme unico [correct definition of the division in the sense of creating two or more parts out of something which was a whole] (Treccani, 2015).

\section{The Detour Principle}

In line with inhibition and the principle of refusal, this principle may facilitate the identification of the meanings within specific contexts, inhibiting immediate and apparently adequate solutions.

Exercise 1. Students may be asked to define a polysemic word in at least three ways, on the basis of the detour principle, suggesting that this could be done in 
relation to:

- What it can be used for?

- Where you can find it?

- Who uses it?

- What can be done with it?

Table 4. The Polysemic Word "Albero": Applying the Detour Principle

\begin{tabular}{|c|c|c|}
\hline \multicolumn{3}{|c|}{ "Pianta" [Plant] } \\
\hline$\bullet$ & What it can be used for & 1) (............. 2) (............ 3) .. \\
\hline$\bullet$ & Where you can find it? & 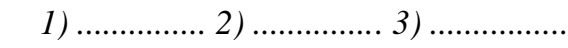 \\
\hline$\bullet$ & Who uses it? & 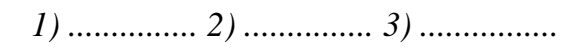 \\
\hline$\bullet$ & What can be done with it? & 1) ............ 2) ..... \\
\hline \multicolumn{3}{|c|}{ "Asta verticale" [Mast] } \\
\hline$\bullet$ & What it can be used for & ....... 2) (.............. 3) \\
\hline • & Where you can find it? & 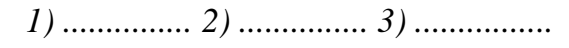 \\
\hline$\bullet$ & Who uses it? & 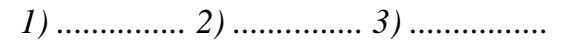 \\
\hline$\bullet$ & What can be done with it? & 1) \\
\hline \multicolumn{3}{|c|}{ "Schema grafico" [Organisational chart] } \\
\hline 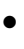 & What it can be used for & 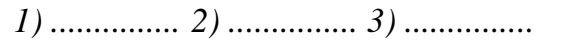 \\
\hline$\bullet$ & Where you can find it? & 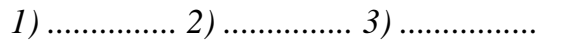 \\
\hline$\bullet$ & Who uses it? & 1) \\
\hline$\bullet$ & What can be done with it? & 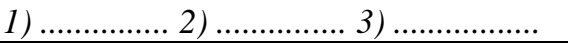 \\
\hline
\end{tabular}

Exercise 2. Students could be asked to define at least three different ways what each specific polysemic word is in order to do the exercise, aware of the detour principle.

Table 6. The Polysemic Word "Banco": Applying the Detour Principle

\begin{tabular}{|c|c|}
\hline \multicolumn{2}{|r|}{ Banco } \\
\hline Istituto bancario [bank] & 1) \\
\hline Mobile [bench/piece of furniture] & 1) \\
\hline
\end{tabular}

Table 7. The Polysemic Word "Guida": Applying the Detour Principle

\begin{tabular}{|c|c|}
\hline \multicolumn{2}{|r|}{ Guida } \\
\hline Azione di guidare [to drive] & 1) \\
\hline Professione [profession] & 1) \\
\hline
\end{tabular}


Table 8. The Polysemic Word "Passato": Applying the Detour Principle

\begin{tabular}{|c|c|}
\hline \multicolumn{2}{|r|}{ Passato } \\
\hline Тетро [time] & 1) 2) \\
\hline Alimento [food] & 1) 2 ) \\
\hline
\end{tabular}

Exercise 3. To verify awareness when applying the detour principle, students may be asked to make up three stories linked to the following words:

\section{Saggio}

a) inteso come "persona dotata di saggezza" [meaning wise man]

b) inteso come "prova" [meaning show/soiree]

\section{Divisione}

a) intesa come "l'atto di dividere" [meaning the act of dividing a whole]

b) intesa come "operazione matematica" [meaning mathematical operation]

\section{Conclusions}

The complex situation characterizing the current Italian educational settings, calls teachers to make a real investment in their education and training through the development of viable strategies and problem solving and through the creative and flexible organization of didactic processes. The production of new ideas, the ability to approach problems in an innovative way, flexibility, adaptation to change and the ability to find detours are not only the characteristics of creative thinking, but also to coherently fit with the aim and principles of inclusion and the prospect of simplex didactics.

Currently, in Italy, there is no obligation to carry out specific training paths aimed at exercising creativity, with the exception of specialized courses for teachers trained in special education (Ministerial Decree 30th September 2011), reserved for teachers already holding a teachers' warrant.

It is therefore necessary to reflect on the need for the possible planning of specific training paths aimed at teachers to acquire the ability to find and apply detours. In this sense, the simplex laboratories, aimed to promote and develop problem-solving strategies in teachers and learners, are considered an original and "vicarious" attempt to find alternative methods of teaching action to deal with the complexity of the processes of teaching and learning and to ensure the educational success of all learners. 


\section{References}

Argyris, C., \& Schön, D. A. (1974). Theory in Practice: Increasing Professional Effectiveness. San Francisco: Jossey Bass.

Beaudot, A. (1976). Il problema della creatività nella scuola [The problem of creativity in schools]. Torino: SEI.

Berthoz, A. (2012). Simplexity. Simplifying Principles of a Complex World. USA: Yale University Press.

Berthoz, A. (2015). La Vicarianza. Il nostro cervello creatore di mondi [Vicariance. Our Brain Creator of Worlds]. Torino: Codice Edizioni.

Boden, M.A. (1990). The Creative Mind. Myths and Mechanism. New York: Basic Books.

Canevaro, A. (2013). Scuola inclusiva e mondo più giusto [Inclusive schools and the creation of an equal world]. Trento: Erickson.

Cesa-Bianchi, M., Cristini, C. \& Giusti, E. (2009). La creatività scientifica. Il processo che cambia il mondo [Scientific Creativity. The process that changes the world]. Roma: Sovera Edizioni.

Chiappetta Cajola, L.C., \& Ciraci, A.M. (2013). Didattica inclusiva: Quali competenze per gli insegnanti [Inclusive Didactics: Which competencies for teachers?]. Roma: Armando Editore.

Darling-Hammond, L., Bransford, J., LePage, P., Hammerness, P., \& Duffy, H. (Eds.) (2005). Preparing teachers for a changing world: What teachers should learn and be able to do? San Francisco, CA: Jossey-Bass.

de Bono, E. (1998). Creatività e pensiero laterale [Lateral thinking: a textbook of creativity]. Milano: Rizzoli.

European Agency for Development in Special Needs Education (2012). Profile of Inclusive Teachers, Odense, Denmark: European Agency for Development in Special Needs Education. Retrieved from: http://bit.ly/1pLkYCI.

Gardner, H. (1983). Frames of Mind. New York: Basic Book Inc.

Ghaye, A., \& Ghaye, K. (1998). Teaching and learning through critical reflective practice. London: David Fulton.

Goleman, D., Ray, M., \& Kaufman, P. (1999). Lo spirito creativo [The creative spirit]. Milano: Rizzoli.

Green, A., Wolf, A., \& Leney, T. (1999). Convergence and Divergence in European education and training systems. London: Institution of Education.

Guilford, J.P. (1950). Creativity. American Psychologist, 5(9), 444-454. DOI: $10.1037 / \mathrm{h} 0063487$.

Guilford, J.P. (1967). The Nature of Human Intelligence. New York: McGraw-Hill.

Mednick, S.A. (1962). The associative basis of the creative process. Psychological Review, 69(3), 220-232. DOI: http://dx.doi.org/10.1037/h0048850

Ministero dell'Istruzione, dell'Università e della Ricerca [Ministry of Education]. Legge 8 ottobre 2010, n. 170 - Nuove norme in materia di disturbi specifici di apprendimento in ambito scolastico [Law 8 October, 2010, n. 170 - New school regulations for Specific Learning Disorders].

Ministero dell'Istruzione, dell'Università e della Ricerca [Ministry of Education]. Decreto Ministeriale 12 luglio 2011, n. 5669 - Disposizioni attuative della Legge 8 ottobre 2010, Nuove norme in materia di disturbi specifici di apprendimento in ambito scolastico [Ministerial Decree 12 July, 2011, n. 5669 - Implementation of Law 8 October, 2010, New school regulations for Specific Learning Disorders].

Ministero dell'Istruzione, dell'Università e della Ricerca [Ministry of Education]. Decreto Ministeriale 30 settembre 2011 - Criteri e modalità per lo svolgimento 
dei corsi di formazione per il conseguimento della specializzazione per le attività di sostegno, ai sensi degli articoli 5 e 13 del decreto 10 settembre 2010, n. 249 [Ministerial Decree 30 September, 2011 - Criteria and modalities for the delivery of specialisation courses for special education teachers, according to the Articles 5 and 13 of the Legislative Decree 10/09/2010, n. 249].

Ministero dell'Istruzione, dell'Università e della Ricerca [Ministry of Education]. Decreto Ministeriale 16 novembre 2012 - Indicazioni Nazionali per il curricolo della scuola dell'infanzia e del primo ciclo di istruzione [Ministerial Directive 16 November, 2012 - National Curriculum Indications for Nursery and Primary School Years].

Ministero dell'Istruzione, dell'Università e della Ricerca [Ministry of Education]. Direttiva Ministeriale 27 dicembre 2012 - Strumenti d'intervento per alunni con Bisogni Educativi Speciali e organizzazione territoriale per l'inclusione scolastica [Ministerial Directive 27 December, 2012 - Intervention tools for pupils with Special Educational Needs and territorial organisation for inclusive education].

Ministero dell'Istruzione, dell'Università e della Ricerca [Ministry of Education]. Circolare Ministeriale 6 marzo 2013, n. 8 - Direttiva Ministeriale 27 dicembre 2012 Strumenti d'intervento per alunni con bisogni educativi speciali e organizzazione territoriale per l'inclusione scolastica. Indicazioni operative [Ministerial Circular 6th March, 2013, n. 8 - Ministerial Directive 27 December, 2012 "Intervention tools for pupils with Special Educational Needs and territorial organisation for inclusive education". Guidelines for the implementation].

Organisation for Economic Co-operation and Development (2005). Teachers Matter: Attracting, Developing and Retaining Effective Teachers. Paris: OECD.

Recommendation of the European Parliament and of the Council of 18 December 2006 on key competences for lifelong learning (2006/962/EC).

Rivkin, S.G., Hanushek, E.A., \& Kain, J.F. (2005). Teachers, Schools, and Academic Achievement. Econometrica. 73(2), 417-458. DOI: 10.1111/j.14680262.2005.00584.x

Rivoltella, P.C. (2012). Neurodidattica. Insegnare al cervello che apprende [Neurodidactics. Teaching the learning brain]. Milano: Raffaello Cortina Editore.

Rivoltella, P.C., \& Rossi, P.G. (2012). Introduzione. In P.C. Rivoltella \& P.G. Rossi (Eds.), L'agire didattico. Manuale per l'insegnante [Didactic Practices. A Manual for Teachers] (pp. 7-22). Brescia: La Scuola Editrice.

Rossi, P.G. (2011). Didattica enattiva. Complessità, teorie dell'azione, professionalità docente [Enactive Didactics. Complexity, Theory of Action, Teaching Profession]. Milano: Franco Angeli Editore.

Runco, M.A., \& Richards, R. (1997). Eminent creativity, everyday creativity, and health. Greenwich, CT: Ablex.

Runco, M.A. (1999). Time and Creativity. In M.A. Runco, \& S. Pritzker, (Eds.), Encyclopedia of Creativity (pp. 659-663). San Diego, CA: Academic.

Schön, D. (1983). The reflective practitioner: How professionals think in action. New York: Basic Books.

Schwerdt, G., \& Wuppermann, A.C. (2011). Is traditional teaching really all that bad? A within-student between-subject approach. Economics of Education Review, 30 (2), 365-379. DOI: 10.1016/j.econedurev.2010.11.005.

Sibilio, M. (2014). La didattica semplessa [Simplex Didactics]. Napoli: Liguori Editore. 
Sternberg, R.J. (Ed.). 1999. Handbook of creativity. New York: Cambridge University Press.

Torrance, E.P. (1966). Torrance test of creative thinking. Directions manual and scoring guide. Lexington: Personnel Press.

Treccani, G. (2015). Vocabolario della lingua italiana on line [Italian Dictionary]. Retrieved from http://bit.ly/1HMnpZl

United Nations (2006). Convention on the Rights of Persons with Disabilities. Retrieved from http://bit.ly/20R24tw.

Van Manen, M. (1993). The tact of teaching: The meaning of pedagogical thoughtfulness. Ann Arbor, MI: The Althouse Press.

World Health Organisation (Ed.) (2007). International Classification of Functioning, Disability, and Health: Children \& Youth Version: ICF-CY. Geneva: World Health Organisation. Retrieved from http://bit.ly/1MrTo2Y.

World Health Organisation (Ed.) (2011). International Classification of Functioning, Disability, and Health. Geneva: World Health Organisation. Retrieved from: http://bit.ly/1MrTo2Y.

Figures' Sources

Fam i ly tree. Retrieved from http://bit.ly/1SoQ4JC.

Annual Tree Program. Retrieved from http://bit.ly/106Tlwg

Boat Clip Art. Retrieved from http://bit.ly/1NPD5Sd.

Bank. Retrieved from http://bit.ly/1QAd1uX.

School Bench. Retrieved from http://bit.ly/1MNlepP.

Drive. Retrieved from http://bit.ly/1MbxDXu.

Guide. Retrieved from http://bit.ly/1MbxJhO.

Minestrina verdure con pasta svezzamento mes. Retrieved from http://bit.ly/1H0baxA.

Past, Present, Future. Retrieved from http://bit.ly/1SNCNey.

Wise man. Retrieved from http://bit.ly/1RTy8qI.

Show. Retrieved http://bit.ly/1RTyU7b.

Divide. Retrieved from http://bit.ly/1PFLlEf.

Arithmetic operation. Retrieved from http://bit.ly/1MrW8xp. 